Bureaus of Land Man monent

Librany

Danver Sorvica Center 


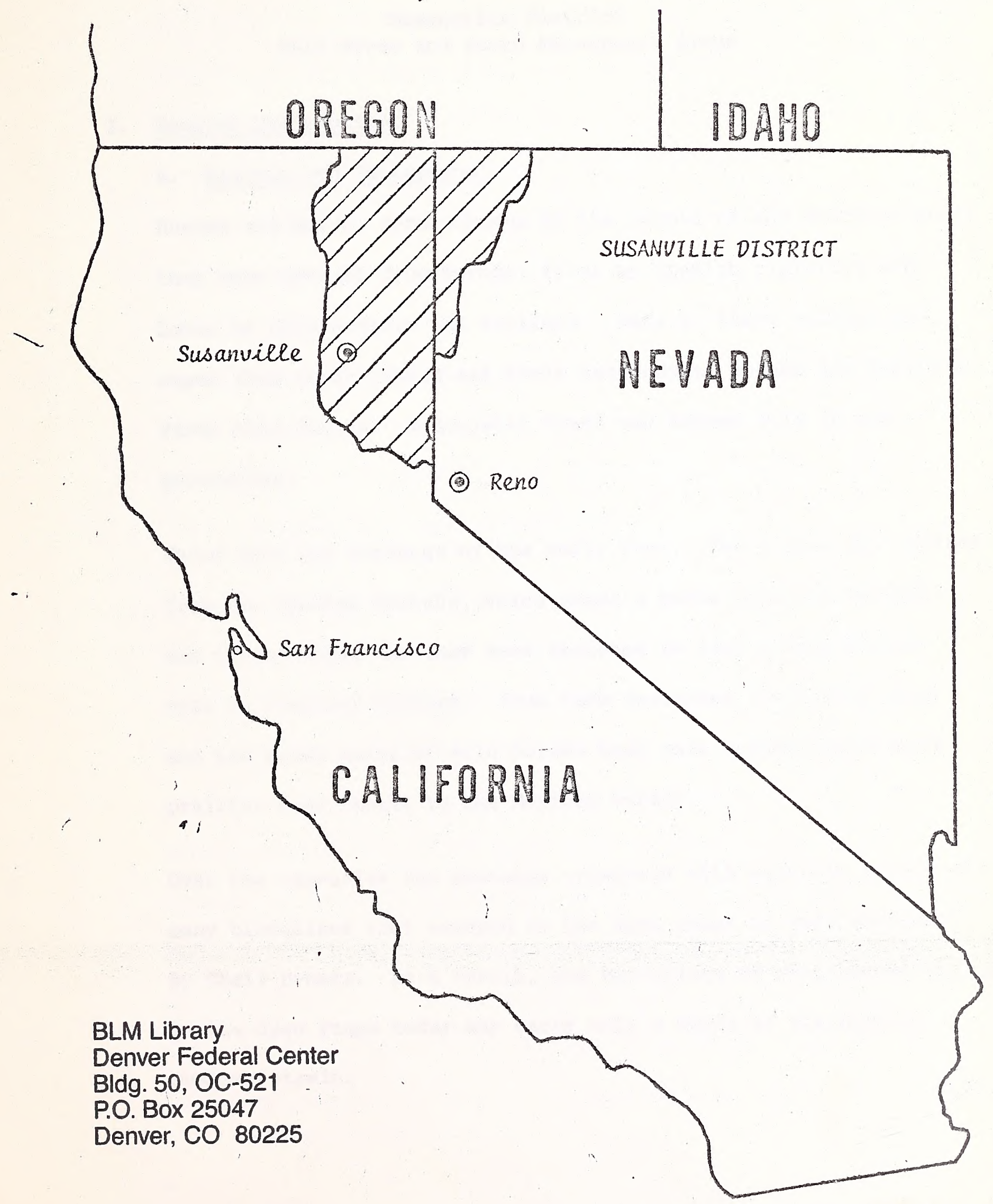

March, 1974

1
Bureau of Land Wanagament 
Vistidi] MJJA ystre istabe7 yovned

1Sc-00 .0ב pbia

PAOZS xo8 09 ass08 00 yevnod 


\section{ENVIRONMENTAL ANALYSIS}

Susanville District

Wild Horse and Burro Management Areas

I. General Description:

A. History and Background:

Horses and burros were unknown to the people of the Americas until they were brought from Europe, first by Spanish explorers and later by missionaries and settlers. Many of these animals escaped from their owners and their descendants became the Nation's first wild horses. A domestic breed can become wild in one generation.

These were the mustangs of the early West. Their name was derived from the Spanish Mestaño, which means a horse that has strayed and turned wild, and they were destined to play a significant role in frontler history. From them descended the Indian pony and the great herds of wild horses that once roamed the Western prairies from Canada to the Mexican border.

Over the centuries the mustangs crossbred with domestic horses of many bloodlines that escaped to the open range or were abandoned by their owners. As a result, the bloodlines of wild horses living on the open range today carry only a trace of the Spanish mustang strain. 

Indians tamed some of the wild horses and used them to reign over the West until the coming of railroads, ranchers; and homesteaders spelled the end of their dominion. After World War I, hundreds of ranchers went broke. Many turned their horses loose to join the hundreds of thousands of wild horses already running on unfenced ranges. In addition, many horses were abandoned after mechanized farming eliminated the need for large numbers of draft animals. Soon there were more horses than the open range could feed, and wild horses were eating grass that ranchers wanted for their livestock. Finally, in the $1920^{\prime} \mathrm{s}$ and again in the $1940^{\prime} \mathrm{s}$, man and nature both took a hand. Starvation, roundups, and diseases drastically reduced the numbers.

The wild horse and the wild burro are symbolic of a unique era of our national history, and a free-roaming herd of these animals grazing across the open range has great aesthetic appeal. Congress, in recognition of these values, has passed two Federal lows to protect wild horses. Public Law 86-234, passed in 1959, makes it illegal to use aircraft or motorized vehicles to capture or kill wild horses. Public Law 92-195, passed in 1971, places wild horses and burros roaming on national resource lands under the jurisdiction of the Secretaries of the Interior and of Agriculture for protection, management and control. It provides a penalty for harassing, capturing, killing, or selling wild horses, and prohibits 

the processing of wild horses into any commercial product. The maximum penalty is a fine of $\$ 2,000$ and imprisonment for one year.

The act of 1971 provides for the establishment of an advisory board to make recommendations on the management and protection of wild horses and burros.

B. Objective and Possible Alternatives for Accomplishment:

1. Objective

To manage wild free-roaming horses and burros under prin- . ciples of multiple use, sustained yield and environmental quality, to protect them from unauthorized actions, to manage their habitat in a manner to achieve and maintain an ecological balance and a population of sound and healthy individuals, consistent with P.L. 92-195, the Bureau's multiple use planning system and the Taylor Grazing Act.

2. Possible Alternatives for Accomplishment

a. Take no action. Allow natural increases in the horse and burro populations to continue unchecked until they fill every environmental niche they are properly capable of filling. Maintain current livestock use.

b. Reduce horse and burro numbers. Control the number of horses and burros at some level below present populations by periodically capturing and moving to less populated areas, 

giving the animals away or destroying those animals no longer contributing to the ecologic well-being of the herd. Maintain current livestock use.

c. Reduce livestock use. Allow less livestock on the public lands, shorten the grazing season, or both. Maintain wild horse and burro populations at present levels.

d. Reduce wildlife numbers. Reduce deer and antelope populations by controlled hunting; reduce rodent and rabbit populations by poisoning. No predator control. Maintain wild horse and burro populations at prescribed levels and maintain present livestock use.

e. Reduce 1 ivestock use and horse and burro numbers. Reduce the animal classes in proportion to their present use. Maintain animal numbers at prescribed levels.

f. Maintain livestock use and horse and burro numbers at the present level.

g. Change class of livestock. Convert from cattle to sheep, or from sheep to cattle.

h. Increase the amount of available forage. Increase the amount of avallable forage for all classes by grazing management systems, spraying, seeding, fencing or controlled burning. Maintain all animals at prescribed levels. 

II. Description of the Existing Environment

A. Living and Non-Living Components

1. Vegetation

The present vegetation on much of the spring-sumer-fall range of the wild horse and burro management areas is sagebrush with annual grasses and forbs predominant, but with sufflclent perennfal grasses and forbs to form a potential seed source for these perenntals. The decrease in perenntal grasses and forbs and the increase in sagebrush and rabbitbrush is primarily due to heavy grazing use and Improper season of use in the past. Present grazing use 18 st11l detrimental near water sources, but there is an Increase in perennial grasses and forbs and ground cover on some areas a mlle or more from water and on steep and inaccessible areas. The lack of the later maturing perennials, grasses and forbs with higher nutritive values, greater stabllity of forage production and soll stabflizing root systems is having an adverse 1mpact on range livestock production, wild horses and burros, and upon big game animals.

Much of the winter range area is dominated by a shrub overstory of greasewood or salt desert shrubs and a sparse understory of annual forbs and perennial grasses. This type of range 18 generally most sultable for winter sheep use. There is presently considerable cattle winter use and wild horse and burro use on the area and some of the cattle use extends into the early spring. Early sping use 

on winter range is very detrimental to both perennial shmibs and grasses because stored carbohydrate reserves are greatly depleted and seed production is greatly reduced by grazing use during this season. Livestock production and forage availability for wild horses and burros are presently limited by the low volume of perennial grass production on the winter range.

\section{Animals}

In addition to domestic Iivestock (cattle, sheep and horses), wild horses and burros, deer and antelope consume quite significant amounts of forage. Rabbit and rodent populations periodically increase to high levels and consume significant amounts of forage and plant seeds. Some degree of competition for forage exists among all herbivores. Sage grouse habitat will be adversely affected by poor production of perennial forbs on both meadow and upland sites. Significant competition exists between domestic livestock and big game for desirable browse plants on areas where deer and antelope winter, and on meadows where livestock and wild horses and burros concentrate and destroy critical sage grouse and other wildiffe habitat. Management of ungulate populations is essential to maintain a desirable environment.

Bobcats, coyotes and badgers are the principal carnivores. Coyotes pose a problem for the sheep ranchers, especially at lambing time. Although golden eagles are present within the area, there have been no reports of predation on lambs by this large blrd of prey. 



\section{Land}

There are several mountain ranges in the area where wild horses and burros are presently found. Several of the most prominent are the Granite Range and the Southern portion of the Warner Mountains. There are also some very steep, rocky slopes, but more than half of the entire area is relatively flat to gently sloping. Much of the land surface is stony to very rocky. The rough topography in some of the areas is a significant barrier or impediment to livestock movement, but has less effect upon wild. horses and burros and bis game animals.

4. Water

There are several perennial streams in the area and many perennial springs. There are irrigation reservoirs and numerous small reservoirs that provide water for livestock. However, there are relatively large areas with an inadequate supply of stock water from late spring through early fall. Poor livestock distribution is common throughout the area. Wild horses and burros and domestic livestock use is heavy near perennial water sources while there is little use of forage on the high peaks and ridges.

\section{B. Change Agents}

The principal agents of change can be classified into two categories natural and those that are the result of man's activities. 

The more important natural agents of change are fires resulting from lightning strikes, deer and antelope population changes, rodent population changes, insect population changes, plant diseases and weather. The efficient, early detection and suppression of fires has greatly reduced the degree of change brought by this natural element. Fires had the effect of greatly reducing ground cover on the burned-over area and leaving such areas at least temporarily susceptible to accelerated erosion. The greatest accumulation of fuel for fire generally exists on big sagebrush and western juniper vegetative types with a fairly dense stand of annual cheatgrass. The annual understory grasses mature and produce dry fuel with a low ignition temperature and sagebrush contains oils and resins that make this plant burn readily. An increase in perennial understory grasses through grazing management systems should reduce the incidence of fire and reduce soil erosion hazard following fire, because perennial grasses mature later in the summer and have extensive fibrous root systems.

Deer and antelope use is quite well distributed over the area and the population concentrations under present conditions do not have a very significant effect upon the other elements of the ecosystem.

Rodent populations fluctuate greatly over a few years. Jack rabbit populations do increase to the point of competing with large herbivores for forage on limited areas for a year more before declining in population. Small rodent populations occassionally increase to the point 

of partially depleting grass seedings or native grass stands on sagebrush spray areas, but seldom reduce production for more than a year or two in succession.

Grasshopper populations occassionally increase to a point of reducing forage on. very limited areas for a year or two in succession.

Sagebrush moth (Aroga websteri) occassionally increases to the point of significantly reducing sagebrush stands. This is generally considered beneficial in terms of forage production.

The incidence and effect of plant diseases are not well known, but are probably not very significant in their effect upon forage production or other factors of the environment.

Weather has drastic short term effects upon forage production and plant composition where annual grasses and forbs are the predominant understory plant species. Weather also has a direct effect upon animal and insect populations, and thus an indirect effect upon flora.

The impact of man's use, through livestock grazing, has been greater than all natural agents combined. In general, grazing use has had an adverse effect upon the other elements of environment because of excess stocking rates, poor distribution of I1vestock over the area and improper seasons of use. The release of unwanted horses and burros onto the National Resource Lands has had an adverse impact on forage and water resources and wlldife habitat of upland game birds. 

Rallroad fires and other man caused fires have had a significant impact on the forage resources and wlldife on limited areas. In some instances, the effect of fire has been an adverse effect upon forage production and other range resources.

Hunting, flshing, off-road vehicle use and other recreational uses have not had a significant impact upon forage production or livestock and wild horse and burro use on the range.

Water development for livestock use has generally had a beneficial. Impact upon other uses of the land, but in some instances such developments have extended the area subjected to grazing use and have had an adverse impact under the present level of grazing management. 



\section{Ecological Interrelationships}

1. Plant Succession

The vegetative sites within the wild horse and burro management area can be broadly classifled by topographic position as:

(1) closed basins, (2) outwash pla1ns, (3) well-dralned uplands,

(4) semi-wet areas and dralnage courses, and (5) mountain peaks and ridges.

The principal vegetative types, their composition and the area occupled by each are shown an Table 1. Vegetation, Present . Situation and Profected Climax. Wild Horse and Burro Hanagenent Areas - Susanville District.

The sagebrush type is the largest type and is well adapted to a broad range of sites. The low sagebrush (Artemisia arbuscula) occurs generally on the shallow, stony sites of the well-drained uplands. Sandberg bluegrass (Poa secunda) and a great variety of annual forbs are principal understory plant assoclates at the lower seral stages of succession. Such perennial grasses as squirreltall (Sitanion hystrix), needlegrass (Stipa thurberiana), Idaho fescue (Festuca 1dahoens1s) and bluebunch wheatgrass (Agropyron splcatum) are present in significant quantitles at a higher stage in the plant succession. Such perennial forbs as hog fennel (Lomatium spp.d, bighead clover (Trifollum macrocephalum), beard-tongue (Penstemon spp.), pussytoes (Antennorla spp.), and fleabane (Erigeron spp.) are more abundant at the higher successional stages than the annual forbs. 


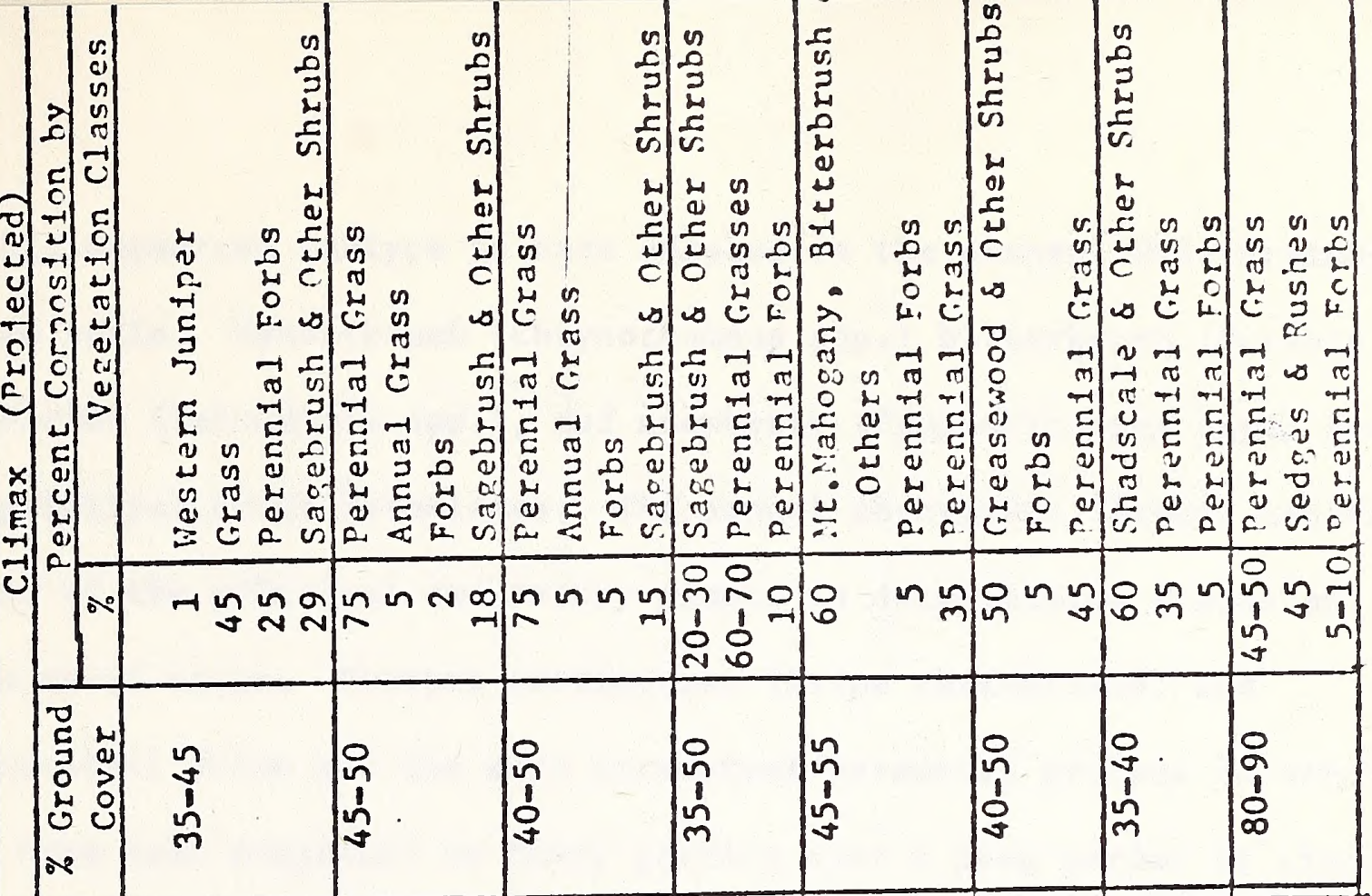

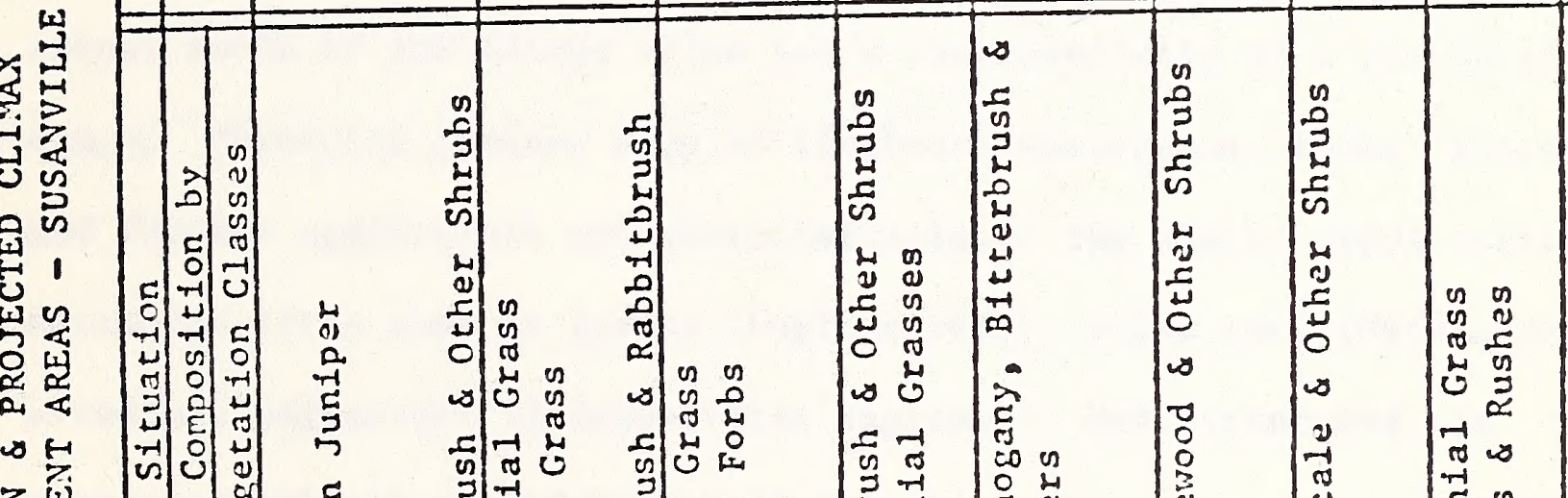

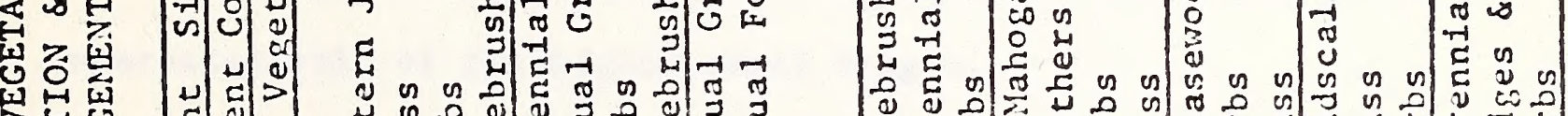

$<$

进疍

$\rightarrow$ es

a $\rightarrow$ 웅

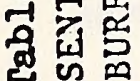

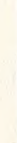

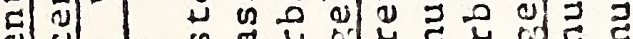

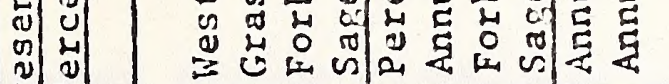

to 4 क्ष

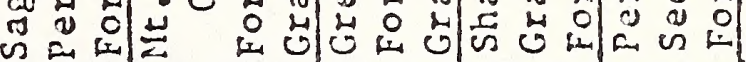

ت્ّ

A. D.

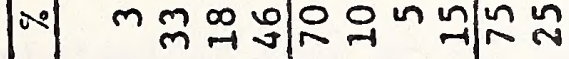

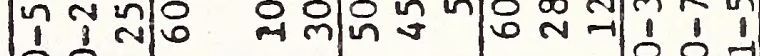
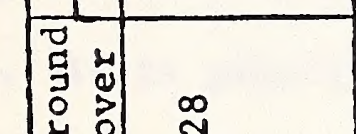

옹 

The b1g sagebrush subtype is best adapted to the deeper, wel1-dra1ned upland solls. Rabbltbrush (Chrysothamnus spp.) b1tterbrush (Purshia spp.). horsebrush (Tetradymla spp.), and snowberry (Symphorlcarpus spp.) are the principal shrub assoclates. The annual cheatgrass (Bromus tectorum) 1s one of the principal understory plants in deterforated stands at a low seral stage. Thurber needlegrass (St1pa thurberlana) and squirreltall often are the most persistent perennlal grasses on areas that have been subjected to heavy grazing over a long perlod of time. Annual forbs of low forage value are a characterlstlc of a low seral stage. Perennlal grasses such as bluebunch wheatgrass, Idaho fescue and Thurber needlegrass are characteristlc of the higher seral stages. Perennial forbs such as luplne (Lupinus spp.), mules ears (Wyth1a mol11s), arrowleaf balsamroot (Balsamorrh1za sag1tata), and butterweed are characteristic of the higher seral stages.

The western Junlper (Junlperous occldental1s) type now extends over a very substantlal part of the well-drained, shallow, rocky, upland 8011s. It is generally limited to areas with 12 inches or more average annual precipitation. The older juntper trees are generally found on rocky ridges wh relatively deep soll between the rocks. Heavy grazing over a prolonged perlod of tlme and suppression of natural flres have greatly extended the area covered by funlper. The principal understory plants are those assoclated with the low sagebrush type on the better sites. 

The perennial grass type is comprised principally of (1) bluebunch wheatgrass on the we11-drained uplands that are steep or rocky and quite Inaccessible to Ilvestock, (2) range seedings of desert wheatgrass (Agropyron desertorum) and other, wheatgrass species, and (3) sagebrush spray areas with mixed stands of perennial grasses Idaho fescue, needlegrass, and squirreltall. Annual cheatgrass and annual forbs are generally assoclated w1th this type. Sagebrush and rabbitbrush generally germinate from seeds or many plants survive the brush spraying with herbicides.

The annual grass type is comprised primarily of cheatgrass and annual forbs. This type occurs on areas where flres have burned over the same ground frequently and where livestock were allowed access to the area after each fire. Sagebrush plants and other shrubs were destroyed by the fire; some perennlal grass specles do not withstand fire and all perennial grasses were heavily grazed following the flres. Th1s type generally occurs on the well-dralned upland sites. There Is about the same potential with respect to plant specles and ground cover as there is for the sagebrush type, or perennial grass type.

The mountain shrub type is found on well-drained, deeper upland solls and on the mountain peaks and ridges. Bitterbrush (Purshia tridentata and P. glandulosa) are the principal dominant shrubs on the well-drained uplands but big sagebrush, rabbltbrush, snowberry, squawapple and currant (Ribes spp.) are shrub associates within this type. Thurber needlegrass, Idaho fescue, bluebunch wheatprass, 

squirre1ta11. Sandberg bluegrass and cheatgrass are the most common grasses assoclated with this type. The annual cheatgrass 1s the predominant grass in the lower seral stages and conversely Idaho fescue and bluebunch grass are most comon as conditions approach climax. The forbs are those common in the big sagebrush type.

The greasewood (Sarcobatus vermiculatus) type is quite extensive. It occurs primarily in the closed basins on moderately deep, alkall so11s. Rubber rabbitbrush (Chrysothamnus nauseosus), spiny hopsage (Grayla spinosa), blg sagebrush, horsebrush (Tetradymia spp.), and shadscale (Atriplex confertifolia) are the principal associated shrubs. Squirreltall is the principal grass at a low seral stage. Great Basln wildrye (Elymus cinereus), needlegrass and salt grass (Distichl1s stricta) are the principal grasses in areas that approach climax condition. Pepperweed (Lepldium perfollatum) and tansy mustard (Descuralnia pinnata) are the most abundant annual forbs on degraded sites at a low seral stage.

The saltbush type 18 best characterized by an abundance of shadscale, but splny hopsage and bud sage (Artemisla splnescens) are also relatively abundant in this type. The type 18 generally found on the oaline solls of the lower outwash plaing and adjacent to the greasewood type. Thurber needlegrass, squirreltall and Indlan rlegrass (Oryzopsis hymenoldes) are the grasses most characteristic of this type. A sparse understory of annual forbs and grasses are indlcative of 
prolonged heavy grazling, especlally during the early spring, months and are characteristic of a low seral stage. Perennial grasses and good ground cover ( $35 \%$ to $40 \%$ ) are character1st1c of a good range condition.

Good meadow grasses and forbs are found on sem1-wet areas or along drainage courses and on moderately deep to deep, non-saline, nonalkallne solls. Nevada bluegrass (Poa nevadens1s), halrgrass (Deschampsia caespitosa), creeplng wildrye (Elumus tritlcoldes), sedges (Carex spp.) and clovers (Trifollum spp.) are the principal spectes in areas in excellent condition. Many of these meador and drainage course areas have been heavily grazed and In many instances have undergone severe gully erosion. Rushes (Juncus spp.), low quallty sedges and such grasses as foxtall (liordeum spp.) and rabbits foot (Polypogon monospellensus) and annual weedy forbs domlnate these degraded sites.

Present range trend 1s $31 \%$ upward, $14 \%$ downward, and $55 \%$ stat1c. Condition classes of the horse areas are $4 \%$ good, $52 \%$ fair, and $44 \%$ in poor condition.

Reference: Un1t Resource Analyses, Steps 2 and 3, Cal-Neva, Cowhead, Home Camp, Massacre, Sheldon, Tuledad Planning Un1ts. 
2. Food Relationships and Community Relationships

Rabbits and small rodent populations periodically increase to a level where they significantly reduce the grass and forb constituents of the vegetation and reduce forage production for livestock on some areas. Chipmunks aid in maintaining bitterbrush stands by caching the seeds in the ground.

Predatory mammals and birds such as coyotes, bobcats, badgers, skunks, golden eagles, hawks and owls, prey upon the rodent populations. However, predators have less influence upon rodent populations than rodent populations have upon predators. When rodent populations are low, the predators attack non-rodent animals, including sheep and calves, more frequently.

Deterioration of vegetation also means an increase of rodent population, plus an increase in predatory mamals until the range condition becomes so poor that even the rodent population will decline.

Most of the available water is derived from springs and reservoirs. Wells are the most important waters on some of the large sagebrush and greasewood Plats.

Concentrations of livestock around springs and reservoirs and on small meadows around water sources and drainage courses are having a very adverse effect upon sage grouse habitat. The availability of high quality porage and water for antelope during the late summer 

and fall on meadow areas. Bitterbrush, mountain mahogany, and other browse plants are also heavily grazed by livestock in late sumer and fall.

The sagebrush moth (Aroga websteri) has had some temporary effect upon the range vegetation. This sagebrush moth's infestations have occurred periodically and have greatly reduced sagebrush on some areas. New sagebrush plants come up from seeds produced in previous years and eventually regenerate the stand. A few thousand acres per year have been affected by the sagebrush moth in years of peak activity. It is not known to what extent the leaf borer (Philotina spp.) may have reduced bitterbrush stands. The extent and importance of grasshopper infestation and use of forage plants within this area has not been determined.

Coyotes are found in all vegetation types, but concentrate in certain areas during certain seasons. In the summer coyotes are widely distributed throughout the wild horse areas and are commonly observed "mousing" on the few freshly cut hay fields found in these areas. During the fall and early winter many young coyotes and some older animals move into lower elevations such as large valleys, and feed on rodents and birds. In mld and late winter, coyotes concentrate in lower elevational flats and valleys. They seem to move into these areas to hunt the rabbit concentrations and feed on carrion.

Bobcats utilize the riparian habitat along the streams or shorelines 
plus rimrock and rock outcrops in sagebrush, juniper and mountain brush types. It is dependent on the small mammals and birds, and carrion if available.

General characteristics of smail game Include a short life span, high reproductive rate and a rapid population turnover rate. Normally, the larger the animal, the longer the life span but the lower their reproductive rate. Short term population levels are governed by annual weather conditions and intrinsic factors so populations can sustain heavy harvest rates. Hunting pressure varies greatly with annual population levels and will normally be self-limiting before reproductive populations are adversely effected. Long term populations are effected by habitat conditions and long range weather patterns. Dove, chukar, and rabbit are adapted to an annual lower successional stage than sage grouse and quail.

Sage grouse are distributed over most of the wild horse areas of the low and big sagebrush types. Meadow areas, breeding complexes and winter concentration areas are essential in the sage grouse ife cycle. The wet meadows provide insects and forbs to young broods in June, and are utilized throughout the summer and early fall. Poor livestock distribution and overgrazing has caused channel erosion, lowering of the water table and eventual loss of the meadow site. 



\section{Aesthetics}

There are several canyons with perennial streams within the proposed wild horse and burro management area. These canyons and streams and characteristic streamside vegetation, composed of quaking aspen and a variety of shrubs, forbs and grasses, are a very welcome break and contrast in an otherwise unvaried, desert landscape.

The scattered high peaks stand out in a bold but harmonious contrast to the adjacent, large closed basins or gently undulating topography of the low hills and drainage courses. Quaking aspen, mountain mahogany, snowbrush, bittercherry and other trees and shrubs often grow in dense stands on the north and east slopes near the summit of these peaks or on the ridges and drainages of the mountain slope. The different colors and growth forms of the trees and shrubs add variety to the landscape.

The mountainous plateaus and rimrocks surrounding the flat basins and low hills define the limits of the landscape.

The roads, bull-dozed fencelines and powerlines that cut directly across the elevation changes of any of the preceding landscape features are very conspicuous and do not harmonize with the landscape. Contoured man-made structures are generally less conspicuous and more harmonious with the landscape. 
Any land uses or natural disturbances such as lightning fires that substantially alter the natural vegetation would have a deleterious effect upon the landscape. 



\section{Human Interest Values}

Educational and Scientific

The area where wild horses and burros are presently found includes several potential natural areas as well as numerous areas that have been identified as potential primitive or back country areas. All of the above sites would be suitable for both student oriented and professional study as environmental education sites. Numerous scenic photographic overlooks or vista points are available both from existing roads and from prominent peaks. Wildlife observation, including wild horses and burros, is easily accomplished due to the number and variety of species available. Sightings and possible nesting sites of prairie and peregrine falcon have also been reported.

\section{Geological}

Essentially this area is typical northern Great Basin country with numerous mountain peaks separated by a variety of rolling hills, lava outcrops, plateaus or tablelands, alkali lakes and valleys, and distinctively cut canyons. Prominent peaks include the Twin Peaks Range, Cottonwood Mountains, Granite Range and Catnip Mountain. Smaller geologic features include numerous natural springs, an area of sand dunes and hills, and several prominent sites containing petrified wood stumps. 
Archeological

Archeological features in the area include rock chipping sites, found principally near springs, wet meadows, and along stream drainages; campsites or rock fortresses usually found along rims above stream courses; rock hunting blinds; rock carvings or petroglyphs on sheer rock faces in numerous canyons; and several prominent caves and overhangs known to have had Indian habitation.

\section{Historical}

The Lassen, Applegate, and Noble pioneer trails all passed through this area. Numerous sites have been located where remnants of the original trails can still be distinguished. Trail markers have been placed to commemorate portions of these pioneer routes.

\section{Recreational}

In addition to general sightseeing in connection with the educational and scientific, geological, archeological, and historical features mentioned above, the primary recreational activities within the area include hunting (deer, antelope, small game and waterfowl), rockhounding, fishing, and camping primarily associated with the above activities.

\section{Local Economic Factors}

There are about 35 livestock operators who are licensed to graze approximately 30,000 head of cattle and 8,000 head of sheep on the area. Most of these ranchers produce primarily Irrigated hay 
crops on their base ranch lands for winter feeding of the livestock they are allowed to run on the public land.

The local economic value of recreation within the area is difficult to quantify. A 1973 Bureau study indicated that northeastern California deer hunters spent $\$ 3.25$ locally per person per day. However, due to the sparseness of privately-operated service facilities much of this would have been spent outside of the area. 



\section{Analysis of Alternatives}

\section{Alternative A}

Take no action. Allow natural increases in the horse and burro population to continue unchecked until they fill every environmental niche they are properly capable of filling. Maintain current livestock use.

The environment in which the wild horses and burros are presently found would be adversely impacted to the extreme. Unchecked, the wild horse and burro populations would increase far beyond the carrying capacity of the land to support them. A similar situation could be cited here as an example of what happens when an animal population has all restraints removed that would normally control population increases, and that is the Kaibab deer herd. Predators were destroyed and no hunting was allowed. In brief, a population explosion occurred, the landscape was denuded, and massive starvation of the deer followed. The population eventually stabilized at fewer numbers than the original level before the factors helping to keep the population in check were removed. Wild horses and burros have no natural predators other than man in this area.

Overgrazing of desirable perennial forage plants would occur first. Continued overgrazing would reduce the vigor and reproduction of desirable forage plants so that ultimately these plants would disappear or be greatly reduced as a percent of vegetative composition. 

As desirable forage plants are decreased by overgrazing, the forage production will decrease to a point where all classes of herbivores have much less forage than needed. The most aggressive animals (wild horses and burros) would probably utilize most of the forage and the least aggressive (deer and antelope) will suffer for lack of for- . age and water. Death losses will be high for both old and young animals among a.ll herbivores.

As plant cover was removed, wide scale soil erosion and water pollution would result. Consequently water temperature and sediment loads would increase reducing present aquatic life. As the hydrologic cycle was disrupted by reduced water percolation and increased evaporation due to hotter ground temperature, the xeric condition would be intensified.

The concept of dominant single species land use is neither compatible with the surrounding private land nor suitable to the area where wild horses and burros are presently found. With no natural predator other than man, uncontrolled population increases would in a short period of time bring this situation about.

The impacts on the ecological processes would be extremely adverse. This area was once a perennial grass habitat type with mixed stands of sagebrush. From past livestock overuse much of the area has been converted to the sagebrush-annual grass seral stage. With wild horses and burros dominating the scene in ever increasing numbers the vegetative types would be degraded even further. Less vegetative cover 
would be evident and less desirable plant species would increase. With the bottom of the food web thus effected all other dependent Iife forms would undergo radical chances in their way of life.

Almost all significant water and marsh lands in the area where horses and burros are presently found receive waterfowl use at some time during the year. Those areas receiving constant use have adequate water and riparian vegetation to provide cover, food and nesting sites. Puddle ducks and Canadian geese inhabit the area from midFebruary until Decenber, but some remain yearlong on the few waters that do not freeze. Unchecked horse and burro populations would effectIvely curtail waterfowl use by overutilizing this critical habitat type.

Shore bird habitat is similar to most duck and coose habitat but includes meadows and mud flats not commonly used by waterfowl. Cottontail rabbit, valley quail, raccoon, beaver and muskrats are all highly dependent on riparian habitat. Many amphibians and several species of minnow-like fishes are also dependent on wet sites and the associated vegetation to carry out their life functions and would be adversely affected by over-utilization.

Wet meadows are also critical sage grouse habitat. They provide insects and forbs to young broods in June, and are utilized throughout the summer and early fall. Maximizing horse and burro numbers and maintaining livestock use at the present level would have a tremendous impact on the sage grouse population by over-utilizing the few remaining productive wet meadows. Poor livestock and wild horse and burro 
distribution and subsequent overgrazing causes channel erosion and lowering of the water table allowing encroachment of undestrable vegetation with eventual loss of the meadow site.

Doves, Chuckar, many rodents and fack rabbits are adapted to an annual or lower successional stage than sage grouse, song birds, quail, cottontail and pigmy rabbit. Therefore, a reduction in range condition (an increase in annual forbs and grasses and reduction of riparian habitat) would precipitate declines in most populations and enhance others.

Deer and antelope populations would obviously suffer with the increased competition for available forage and watering sources. The most desirable range condition for antelope is that in which perennial forbs are abundant from March and into mid-summer, and where high quality browse is available through the fall and winter months. A shortage of summer forage is the chlef habitat factor thought responsible for low deer fawn production and survival. The competition for sumer forage would be intensified if horse and burro populations were allowed to go unchecked.

An increase in small rodents and jack rabbits would enhance the food source for raptors, coyotes and bobcats, although a decrease in cottontail, sage grouse, deer and antelope numbers would most certainly be an overriding factor. Reductions in predator numbers is inevitable unless they switch their primary food source to livestock, 
wild horses and burros. Except for the very young horses and burros this is an unlikely and undependable source of food.

Landscape character would be adversely affected in that the increasing densities of wild horses and burros would reach the point whereby they become the single most dominant use to the detriment of all other natural uses presently being made. This was not the normal healthy condition of wild horses and burro herds in the past, nor is it pleasing to the eyes of man when viewed with the attendant condition of the landscape that would exist.

The impact on the social welfare of the local communities would be tremendous. These communities are dependent on the livestock industry for economic livelihood. If cattle and sheep were no longer able to graze the public lands during part of the year many operations would be forced into bankruptcy. Recreation also contributes strongly to the local economic base which would of course be effected by the loss of hunting.

The local communities are strongly opposed to allowing wild horses and burros to become the dominant use of the public land. Few people anywhere, in fact, advocate uncontrolled wild horse and burro populations. On the national level it's more a question on degree of control and method of control rather than at what level they are to be maintained. 


\section{Alternative B}

Reduce horse and burro numbers. Control the number of wild horses and burros at some level below present populations by periodically capturing and moving to less populated areas, giving the animals away or destroying those animals no longer contributing to the ecologic well-being of the herd. Maintain current livestock use.

The environment wild horses and burros are presently found in would be moderately impacted in a positive manner. The degree of impact would be dependent on the level the animals would be managed.

The present condition of the desirable forage plants, especially perennial grasses, would probably stabilize if all wild horses and burros were removed. The range condition would still continue to deterlorate in much of the area, the rate of deterioration depending on the population level the animals are managed at. As can be seen in Graph I, even with all wild horses and burros removed overgrazing would occur. Ultimately the health and vigor of all herblvores would reflect the condition of the forage plants.

Soil erosion rate would be reduced with the increase in plant vigor and cover, especially the perennial plants which are much better stabilizers than the annual grasses and forbs that presently comprise such a large percent of the plant composition on the range now. Less soil erosion would in turn improve water quality as there would be less siltation. and other pollutants entering the streams, lakes and reservoirs. 


\section{AUM'S}

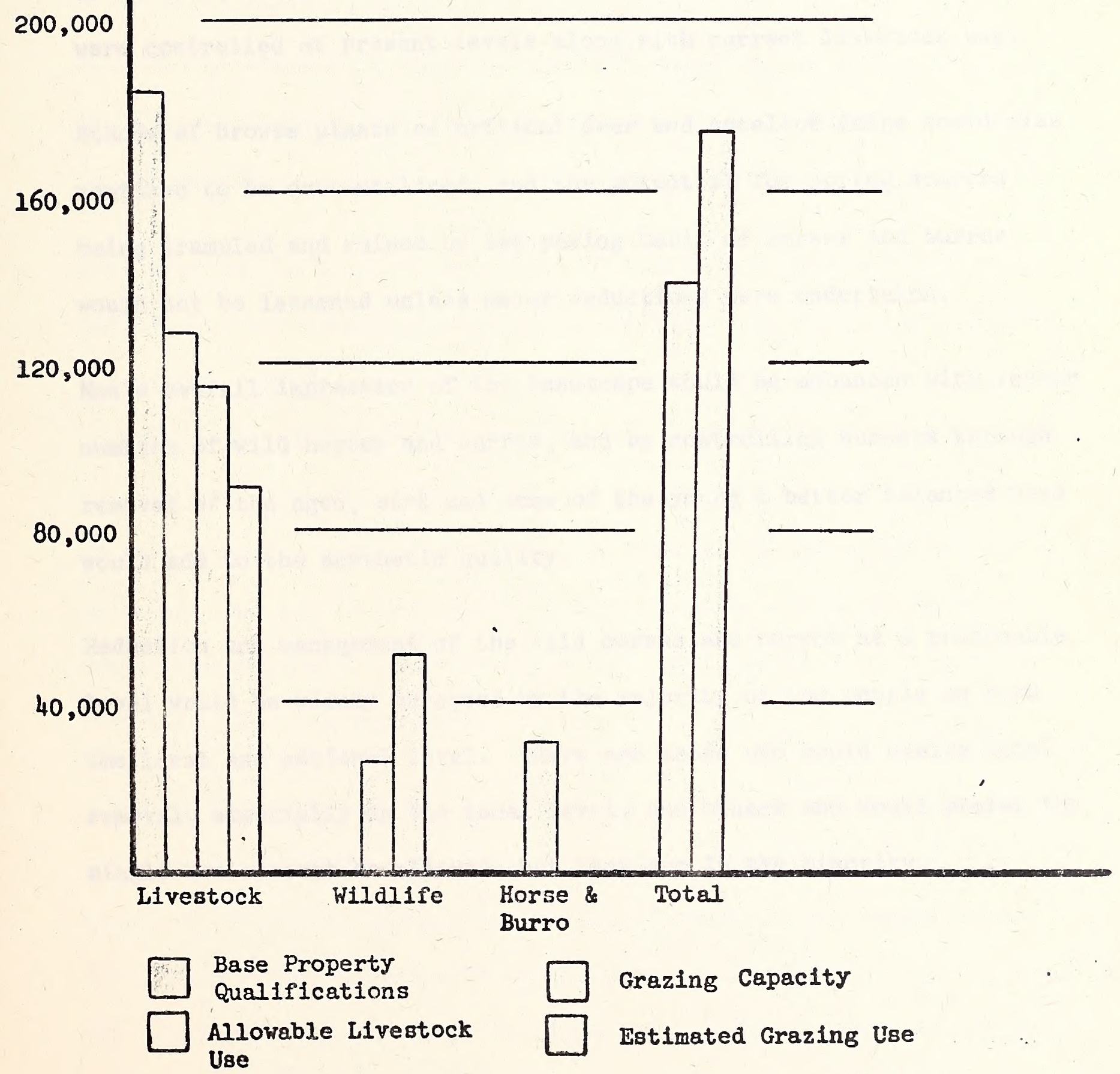


Wild horse and burro reduction and control would have a low to moderate beneficial impact on wildlife if horse and burro numbers were significantly reduced in those areas where range condition is now in a static to downward trend. Localized areas such as sprines, reservoirs, streams, lakes and meadows would most likely continue to deteriorate, or at best, remain in their present condition if horses and burros were controlled at present levels along with current livestock use.

Stands of browse plants on critical deer and antelope rance would also continue to be over-utilized, and the potential for spring sources being trampled and ruined by the pawing habit of horses and burros would not be lessened unless major reductions were undertaken.

Man's overall impression of the landscape would be enhanced with lesser numbers of wild horses and burros, and by controlling numbers throueh removal of the aged, sick and some of the young a better balanced herd would add to the aesthetic quality.

Reduction and management of the wild horses and burros at a reasonable level would be widely accepted by the majority of the people on both the local and national level. There are those who would desire total removal, especially on the local level, and others who would prefer the single use concept be allowed, but they are in the minority. 


\section{Alternative C}

Reduce Iivestock use by allowing less livestock on the public lands, shortening the grazing season, or both. Maintain wild horse and burro populations at present levels.

Reducing livestock use would have a Eenerally beneflcial impact on the environment they are presently utilizing during part of the year.

From the standpoint of maintaining plant vigor and providine for some reproduction of desirable forage plants this alternative would have a beneficial effect.

Soil erosion would be reduced with increased perennial plant cover, and consequently water quality would improve. The degree of improvement would depend on the method and level of reduction. Shortening the season by allowing less Ilvestock on the range in the spring would benefit the perennial plant cover and, as the soll is extremely wet on many sites in early spring, less mechanical damage would occur. Allowing less use in the fall if a fall green-up has occurred would strengthen perennial plant root systems and leave more food reserves for the spring growing season.

Reducing livestock use while maintaining wild horse and burro populations at present levels would have a low to moderate beneficial. impact on wildlife. As cattle tend to concentrate on meadows a reduction in cattle use especially in early summer would definitely be. beneficial to sage grouse. Reducing total livestock numbers allowed 

on the range would have an overall beneflcial impact on most wildilfe species by reducing competition for food and space. Reducine both numbers and season of use would have even a greater beneficial 1mpact, and total removal of livestock from critical wildlife habitat would, of course, be the ideal.

A reduction in Ilvestock use in the fall, especially by sheep, would reduce the competition on essential browse species in critical range types. There is more latitude for adjustment in livestock use as they are by far the greatest forage consumer over most of the area (Graph 1).

Reduction of livestock use would have a beneficial impact on the ecological processes, the degree of impact would, of course, depend on the method and level of adjustment. For example, if there was less sheep use allowed on bitterbrush shoots on deer summer range, plant vigor would be enhanced, more forage would be available the next grazing season, more seed would be set, rodents would have more seeds to eat and cache, and therefore the opportunity for the establishment of new bitterbrush plants would be increased. Further, with a thriving rodent population predators would fare better, and possibly lessen the pressure they presently exert on livestock.

Reduction of livestock would, as with the reduction of wild horses and burros, enhance the general landscape character creating a better overall impression to the observer. A positive visual interpretation 

of the ecosystem to most people would be a fair assumption.

The economic impact on the local livestock industry would be quite adverse for at least a few years. Those livestock opcrations that have the poorest management or are existing on a small profit marein would be the first to go. The better managed or larger operations would possibly absorb the initial impact and eventually benefit through production of more pounds of beef because of the improved range condition. The attitude toward Iivestock reduction at the local level is derinitely adverse, but on a national. level it appears there is a growing regentment toward present intensive use of the public lands by the Iivestock industry. 



\section{Alternative D}

Reduce wildlife numbers. Feduce deer and antelope populations by controlled hunting, reduce rodent and rabbit populations by poisoning, or no predator control. Maintain wild horse and burro populations at prescribed levels end maintain present livestock use.

Reduction of wildlife numbers even at the highest possible forseeable intensity would have only very short tem, if any, benefits in reducing overgrazing of the range. Because of the forage preferences of deer and antelope and their ability to negotiate very rough terrain, at least a portion of the big game use occurs on plants not readily available to either livestock or wild horses and burros. Wildlife plant preferences and seasons of use are not always competitive with that of other herbivores. Reducing big game numbers would have little effect upon the total range forage condition, and therefore, little effect on livestock and wild horse and burro populations.

Soil erosion and water quality would also be enhanced very little throughout the entire area by reducing big game populations.

Specific sites could be improved on a limited basis with an intensive poisoning program for rodents and rabbits, or by intensive big game hunting.

The reduction of major wlldife populations such as deer, antelope, rodents and rabbits in competition for avallable forage with livestock, 

wild horses and burros would have a moderate Impact on most other wildife species. As each species has through time, become adapted to a certain way of life, that is, filling a specific ecologlc niche, reduction or removal of a particular species would not greatly effect adversely those species at approximately the same level of the food web. Direct adverse effects would be noted on those species that are in some way dependent on the species to be reduced. For example, some predator-prey relationships would be out of balance. Overall the ecologic balance would be disrupted to the benefit of some, adversely for others. Ideally, controlled hunts in areas deemed critical for proper resource management would be conducted. Antlerless hunts would not only reduce intraspecific competition but would result in a healthier herd. Poisoning rodents and rabbits would have only short term effects because of their rapid reproductive rates and perhaps more importantly the fact that ingression into the poisoned area by animals outside occurs quite rapialy thereby negating any beneficial impact in a short period of time. Also no rodent or rabbit poison is specific so many non-target species would also be effected.

Direct control measures would have to be conducted by the State Fish and Game Departments as the Bureau of Land Management does not have this authority.

The landscape character cannot be expected to be influenced signifIcantly to the point of change in a vegetative type by reducing a wildlife species. The "browse line" or "clubbing" effect could be 
influenced somewhat in specific areas but this would alter a relatively small part of the environment.

The social welfare of the local communities would be adversely effected as sport hunters, photographers, and the general public that just like to get out-of-doors to observe nature first-hand would go elsewhere. The local merchants would obviously suffer from this loss of business. The general attitude of the people on both the local and national level toward the further reduction of wildlife numbers in any form, especially big game, would be extremely antagonistic. 



\section{Alternative $\mathrm{E}$}

Reduce both livestock use and wild horse and burro numbers. Reduce the animal classes in proportion to their present use and maintain animal numbers at the prescribed levels.

Reduclng both livestock use and wild horse and burro numbers would have a high beneficial impact on all the various components making up the environment.

If all classes were reduced in proportion to their present level of use to a level where forage avallability was in balance with forage consumption, plant vigor and reproduction of desirable forage plants would be promoted.

This in turn would enhance soil stabilization and reduce water pollution, therefore, all species, both plant and animal, that thrive under healthy habitat conditions would prosper. Most wildlife populations would reflect the increased vigor of the environment with healthier animals and increased numbers.

When the range was adjudicated, no forage was ever desicnated for wild horses and burros and only 10 percent was set aside for wildife. Livestock were allowed the balance or 90 percent of the forage. The amount of available forage was based on proper grazing intensity. At the present time livestock allowable use alone exceeds the total carrying capacity of the range (Graph 1). Reductions in all three classes in 

proportion to present use would obviously enhance wildrife, especially if sufficient reductions were made.

Reductions in livestock and wild horses and burros is preferable in that no two species have exactly the same habitat requirements. A variety of animal life in a given environment is generally considered a healthy environment. Therefore, some use by all classes rather than dominant use by one class would be most beneficial for all components making up the environment, including wildlife.

The natural landscape would be enhanced if the vegetative cover, water quality and quantity, and the animals were in balance with each other. Most people are positively stimulated by environments of high quality as opposed to one that is obviously being abused.

The short-term economic impact upon the local livestock industry would be adverse, some of the operations with a small economic base and those having poor management would probably be wiped out. After the livestock operations had adjusted to the reduction the improved range conditions and subsequent increase in pounds of beef raised would probably compensate for the lesser numers of animals allowed to graze the public lands.

The local communties are opposed to any reductions in the livestock use presently being made on the public lands but they are strongly In favor of wild horse and burro reductions. On the national 

level there is far less opposition to livestock reduction on public lands, more opposition being expressed regarding the reduction of the wild horses and burros. 



\section{Alternative $\mathrm{F}$}

Maintain livestock use and horse and burro numbers at the present levels.

Maintaining the animals at the present level would have an adverse impact on the environment. It would result in a continued decline in the vigor and reproduction of desirable forage plants on areas accessible to livestock, wild horses and burros (Graph I), especially the wet meadows where livestock tend to concentrate. All classes of herbivores would ultimately suffer from lack of desirabie forage.

The present condition of the range where the wild horses and burros are now found must be considered to be in less than tolerable condition, approximately $96 \%$ of this range is in either poor to fair condition. Only $4 \%$ is in good condition (Table 2).

The present trend is either static or deteriorating for approximately $69 \%$ of the range. About $31 \%$ is improving at this time (Table 2) but much of the land that shows improvement has had considerable livestock non-use in the last few grazing seasons.

The present overuse being made by grazing animals is neither compatible nor suitable for this range. With continued soil erosion and pollution of the waters the predictable ultimate result is a deteriorated state In which fewer species will be able to exist, and in fewer numbers. 
Table 2

RANGE CONDITION AND TREND

Range Condition

Good

Fair

Poor

Trend

Improving

Static

Deteriorating
Acres

91,000

$1,185,000$

$1,000,000$

Acres

696,000

$1,264,000$

319,000
Percent of Area

$4 \%$

$52 \%$

$44 \pi$

Percent

$31 \%$

$55 \%$

$14 \%$ 

As the carrying capacity is over-extended at the present time, continuine the present use being made by livestock, wild horses and burros will precipitate continued bif game decline in condition and number. Many other life forms will suffer the same fate as their habitat declines in condition.

The actual landscape characteristics would continue to undergo change as the vegetative types deteriorated and were replaced by lower seral forms.

Local economic stability would not be effected as viewed on a shortterm basis, but it would only be a matter of time before it would no longer be economical to operate livestock on the public lands at the same numbers and season of use as at present. Desirable livestock forage in sufficient quantity would just not be there.

Local attitudes and expectations are that we maintain the current Iivestock. use but they would probably want the wild horses and burros reduced if there wasn't enough forage to go around. Some local residents and the public in general are strongly against reducing the present number of wild horses and burros. 


\section{Alternative G}

Change the class of livestock. Convert from cattle to sheep, or sheep to cattle. As there are very few sheep presently being run on the area where wild horses and burros are presently found, the logical conversion to consider would be cattle to sheep.

Conversion of some cattle use to sheep use would result in a better distribution of livestock use over much of the range and less competition between domestic livestock and wild horses and burros for grass. Lack of suitable summer and early fall range for sheep would create a problem in implementing a large scale conversion.

Soil erosion might possibly have a slight beneficial impact with a greater proportion of sheep use in that lighter animals would be less prone to compact or tear up the soil, and as they are normally herded from one area to another rather rapidly there would be less chance of animal concentrations damaging specific sites such as wet meadows.

Less direct water pollution would also occur with fewer cattle and more sheep as cattle are much more prone to pollute water sources with their own wastes.

This type of conversion would probably have a slight beneficial impact on wildlife in general. Specifically, wet meadows and other water sources would undoubtedly show immediate signs of recovery with reduced cattle pressure as sheep do not normally congregate on these sites for 
extended periods as cattle do. This would enhance the habitat for many wildlife species dependent on this habitat type. On the other hand sheep are more competitive with deer and antelope for specific plants than are cattle, especially with deer later in the fall. This could increase the grazing pressure on deer winter range if sheep use were allowed during the fall and winter months.

Converting class of livestock is not very compatible with the uses being made on the adjoining private lands as the majority of the livestock operators have found more profit in cattle and, therefore, are set up to operate cattle and don't have the facilities for handline sheep. There is no question but that the land is suitable for more sheep use than is presently being made. The natural landscape would be impacted slightly in a positive manner as better livestock distribution would relieve some grazing pressure on localized areas.

There would be a high negative impact on the local economy as almost all of the livestock operations are set up for cattle at the present time. Many operations would have difficulty changing over due to lack of adequate facilities, and probably in many cases a lack of knowledge on how to run an economically sound sheep operation.

The attitudes within the local communities to converting their livestock operations would not be favorable. Many cattle operations have been in the same family for several generations and they would want the business to continue in the same manner. It is doubtful if the public on the national level would have strong feelings one way or the other. 


\section{Alternative II}

Increase the amount of available forage for all classes of herbivores by grazing management systems, spraying, seeding, fencing or controlled burning. Maintain all animals at prescribed levels.

This would result in a beneficial impact on the environment. If all the available means of increasing forage were used, the projected in crease of 62,000 animal unit months (Table 3) added to the 140,000 animal unit months presently available would total 202,000 AUM's. The present demand for forage by all classes of herbivores is approximately 175,000 AUM's (Graph 1). This would be highly beneficial In restoring the vegetative resource and decreasing competition among all animals on the range.

With better animal distribution and sufficient available forage the native plants would respond increasing the amount of ground cover thereby helping to stabilize the watershed. Soil erosion should be significantly reduced. Likewise water pollution would be curtailed.

Increasing the amount of available forage would certainly be compatible with adjoining land uses, as well as being quite suitable to the use that is presently being made on the public land.

Wildlife would also benefit directly from such rehabilitation practices as seedings of desirable plants in key habitat types, and also by lesser livestock and wild horse and burro numbers to compete with for living space and other habitat requirements. 


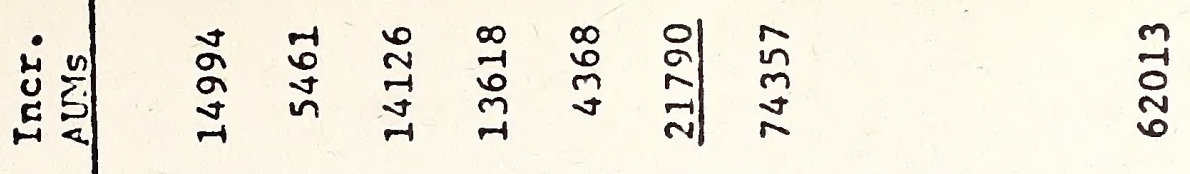

$\frac{2}{2}$

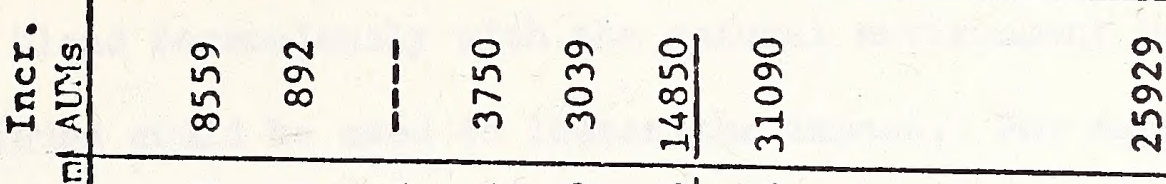

\begin{tabular}{|c|c|c|c|c|c|c|c|c|}
\hline 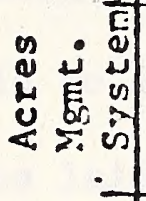 & $\begin{array}{l}0 \\
\infty \\
\infty \\
\infty \\
n\end{array}$ & 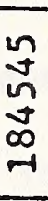 & $\begin{array}{l}\text { aे } \\
\text { on } \\
\text { m }\end{array}$ & 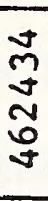 & \begin{tabular}{l}
0 \\
$\infty$ \\
$N$ \\
$\infty$ \\
\multirow{1}{*}{} \\
-1
\end{tabular} & $\begin{array}{l}n \\
2 \\
0 \\
5 \\
5\end{array}$ & $\underset{m}{m}$ & \\
\hline 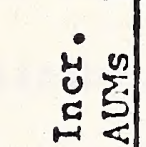 & $\underset{\sim}{\stackrel{O}{N}}$ & $\tilde{N}$ & & & & & $\begin{array}{c}\tilde{n} \\
\tilde{N}\end{array}$ & $\begin{array}{l}\sigma \\
\sigma \\
\sigma \\
-1\end{array}$ \\
\hline
\end{tabular}

4

e

H

(1) a

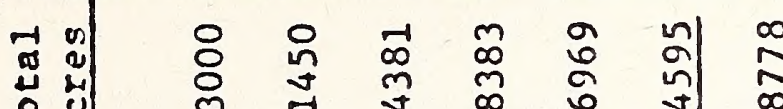

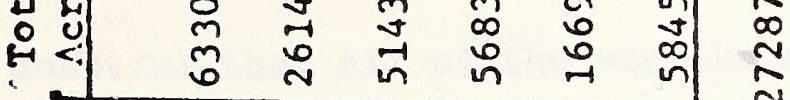

8

a

4)

ज 3

约

8

ज्ञ

द

옹

×

욘

$\rightarrow$

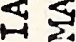

곤

닌 品

ये

$<$ है

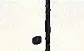

디 $\quad 0 \quad \infty$

$\infty$

ü

孚

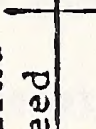

a

$\stackrel{m}{a}$

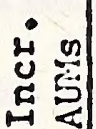

กั $\stackrel{n}{N} \stackrel{N}{N}$

in

2.

On $\cong$

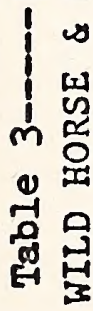

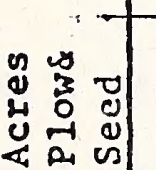

$n_{n}^{n}$
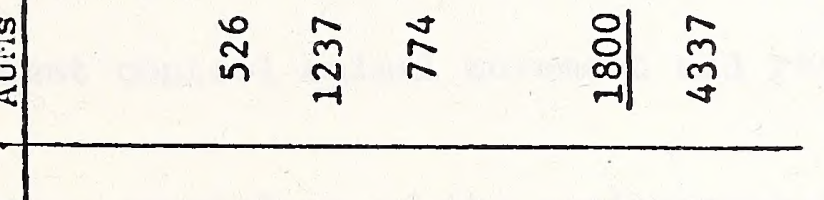

in $\stackrel{\ddot{n}}{\text { n }}$

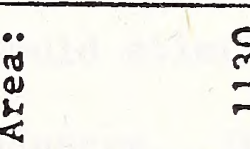

$\frac{1}{1}$

is

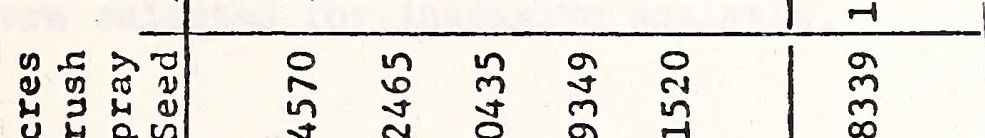

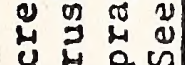
क

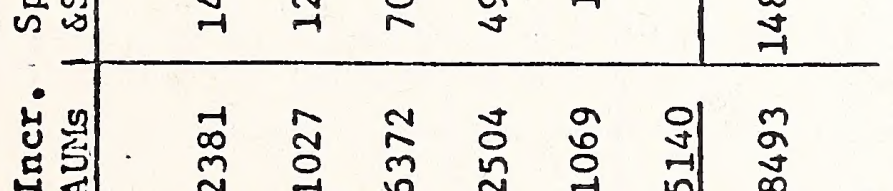

iे ले $0^{\infty}$ ॥

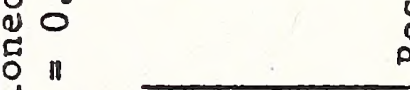

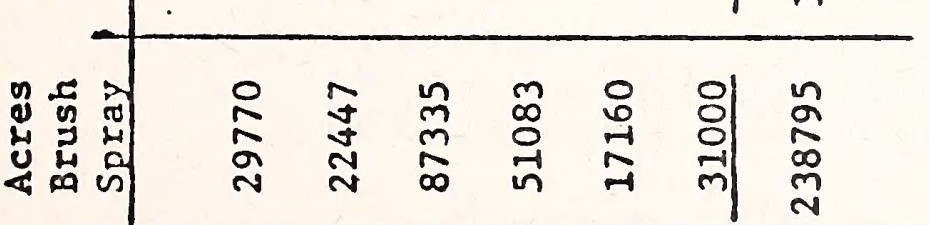

مि

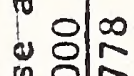

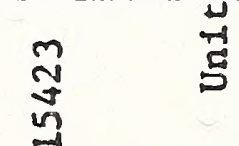



It is doubtful that all of the various means of increasing forage would blend harmoniously with the natural environment but various techniques could be used to lessen the impact. For example, seedings could be interspersed with islands of untreated sagebrush; or fencelines laid out to follow the natural topographic contours without skylining, rather than running several miles in a straight line or locating fences on ridge tops where they are visible from a considerable distance.

Any increase in available livestock forage would stimulate the local economy through benefits to the livestock industry. There would be some resistance on the part of ranchers and probably from wild horse organizations to the implementation of intensive grazing management systems that control animal movement and require maintenance.

Table 4 is a comparison of the environmental impacts within the several alternatives analyzed. Those components of the environment that appeared to be the most significantly affected by the alternatives were selected for intensive analysis. 


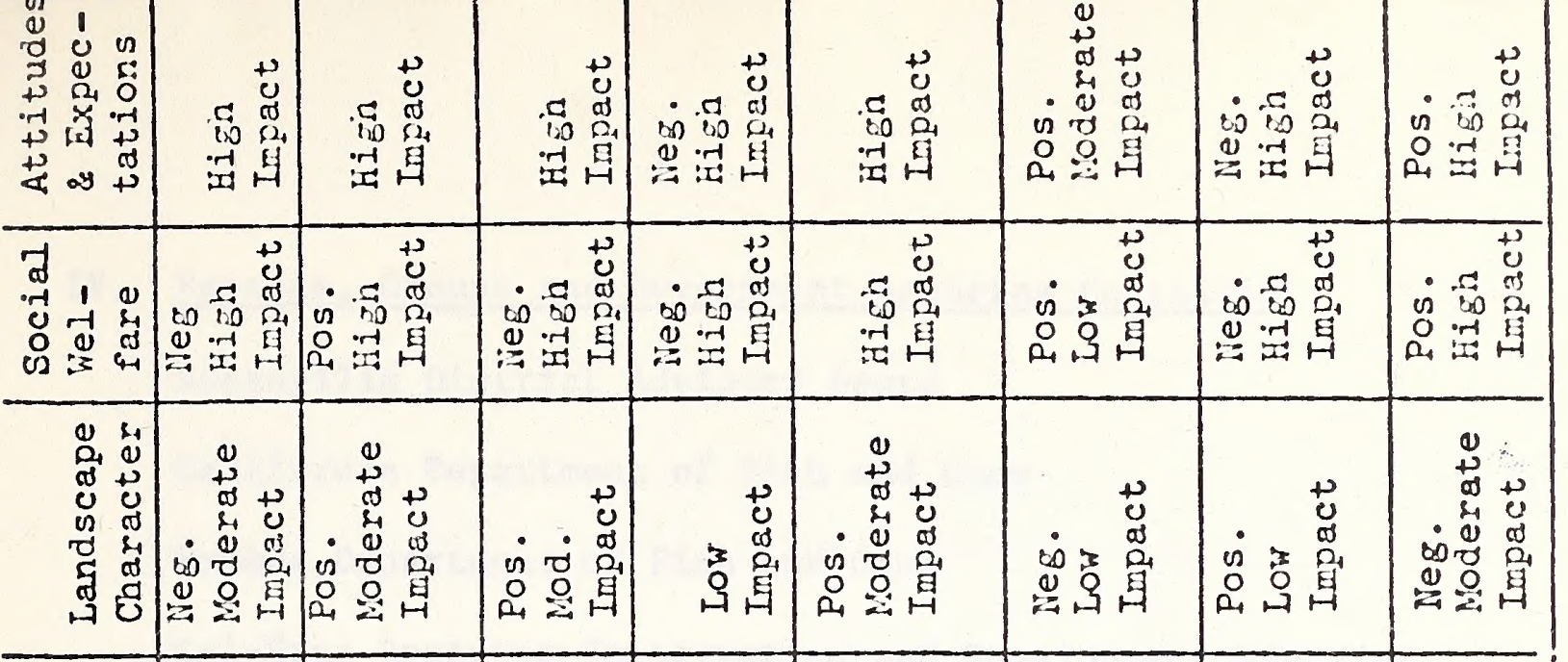

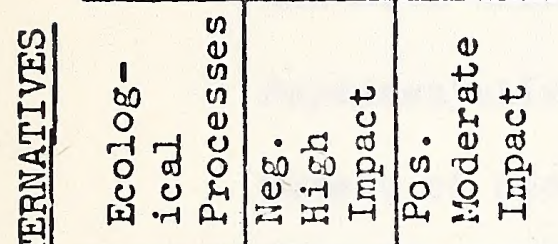

\begin{tabular}{|c|c|c|c|c|}
\hline 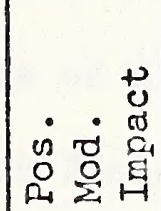 & 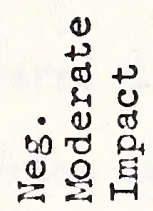 & 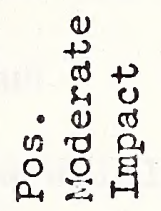 & 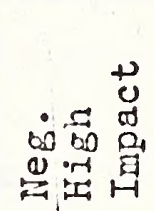 & 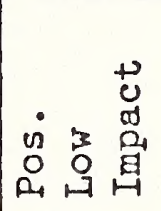 \\
\hline
\end{tabular}

\begin{tabular}{|c|c|c|c|c|c|c|c|c|}
\hline 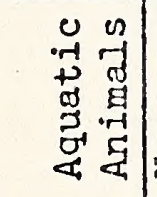 & 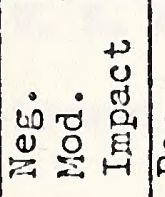 & 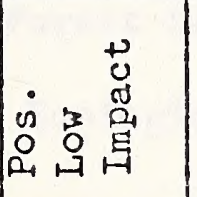 & 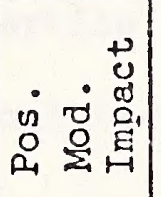 & 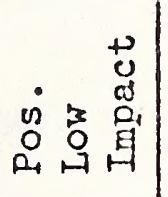 & 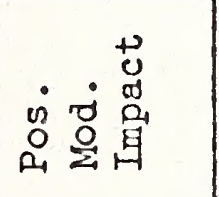 & 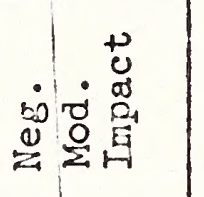 & 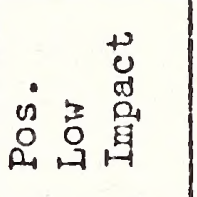 & 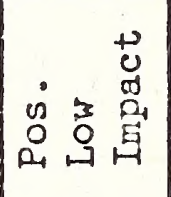 \\
\hline 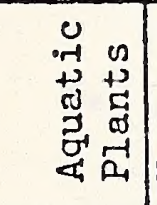 & 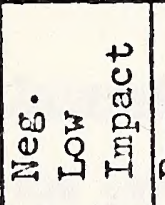 & 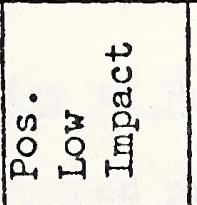 & 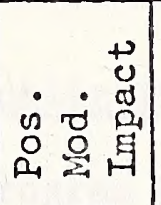 & 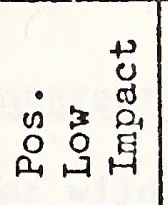 & 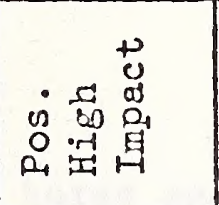 & 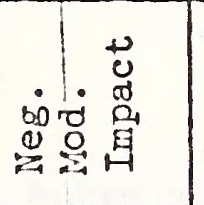 & 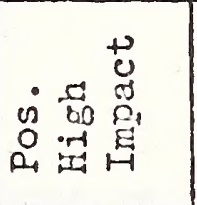 & 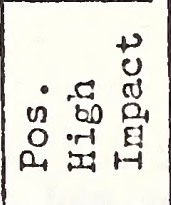 \\
\hline 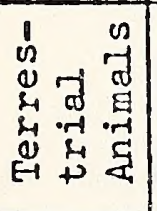 & 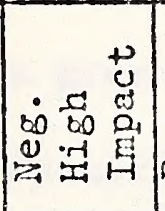 & 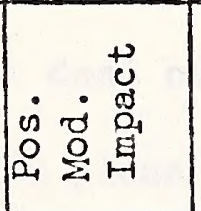 & 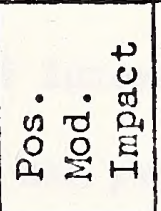 & 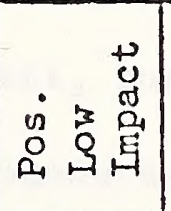 & 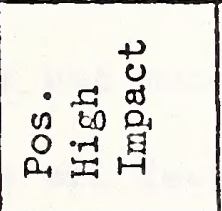 & 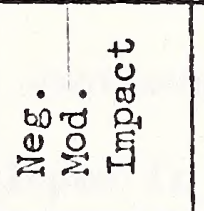 & 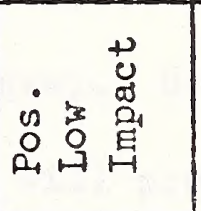 & 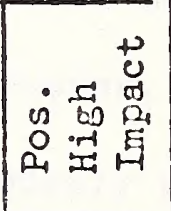 \\
\hline 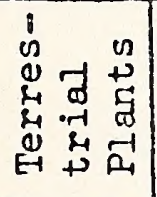 & 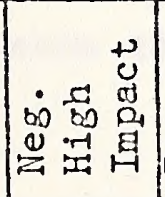 & 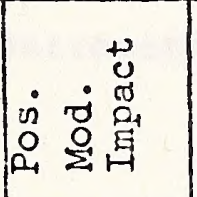 & 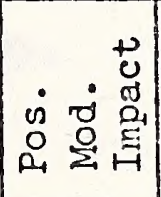 & 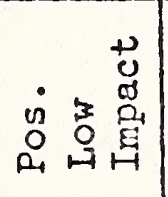 & 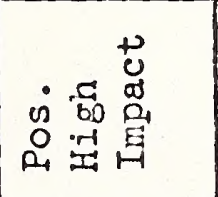 & 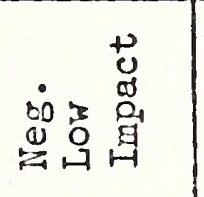 & 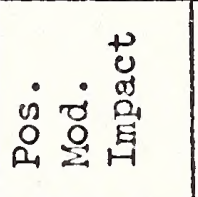 & 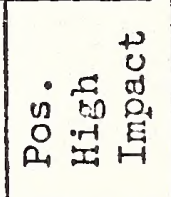 \\
\hline 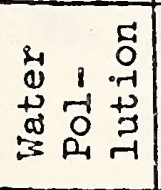 & 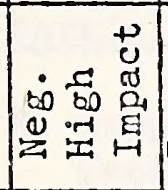 & 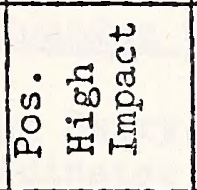 & 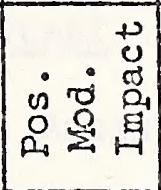 & 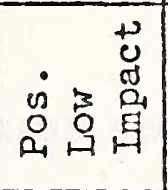 & 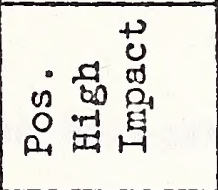 & 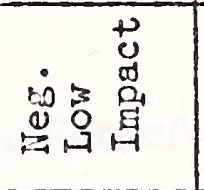 & 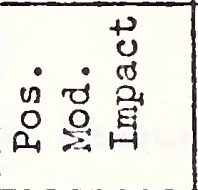 & 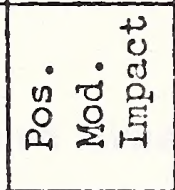 \\
\hline 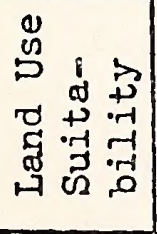 & 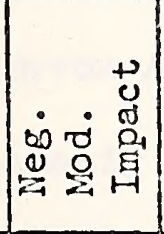 & 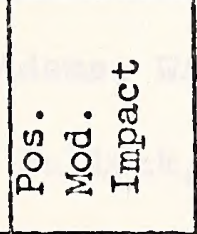 & 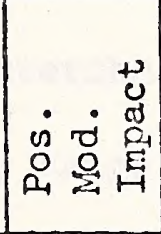 & 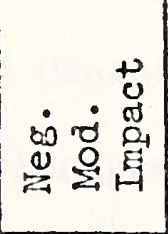 & 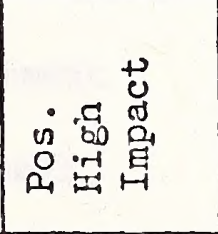 & 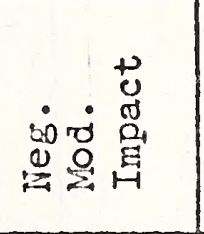 & 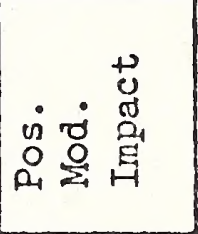 & 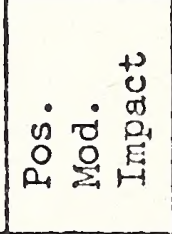 \\
\hline 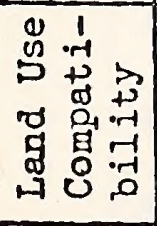 & 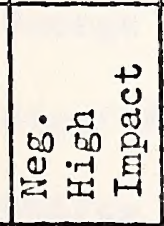 & 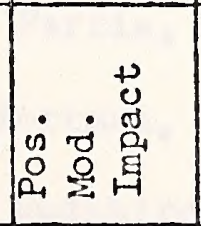 & 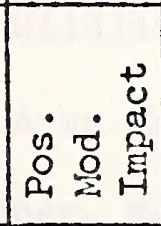 & 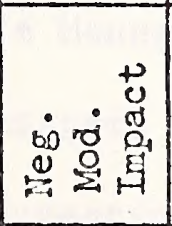 & 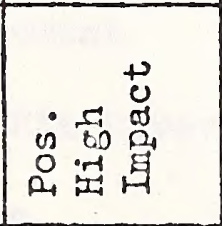 & 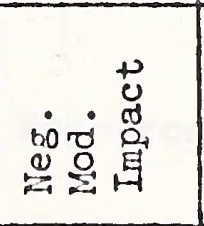 & 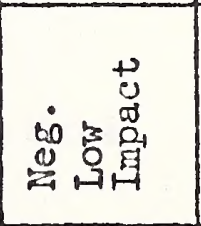 & 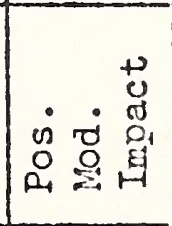 \\
\hline 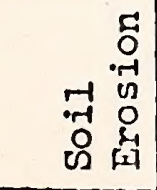 & 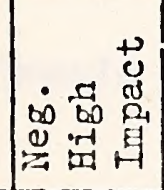 & 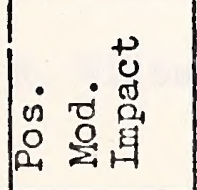 & 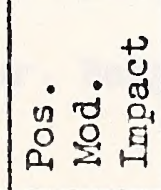 & 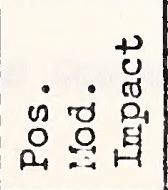 & 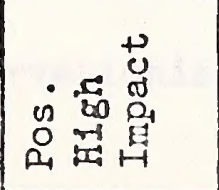 & 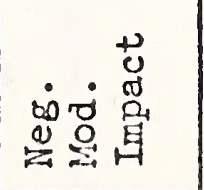 & 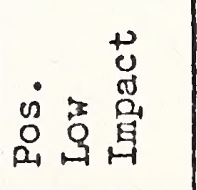 & 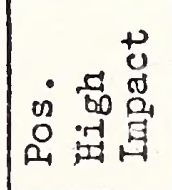 \\
\hline 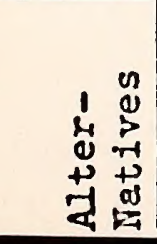 & 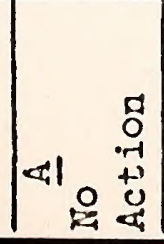 & 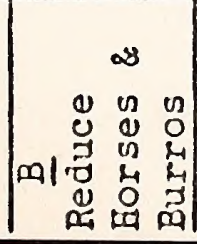 & 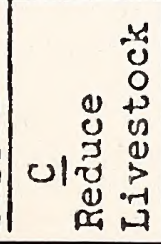 & 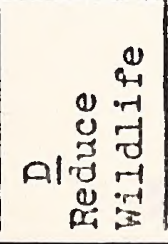 & 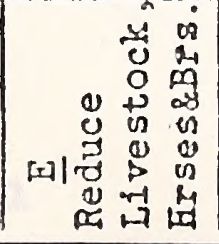 & 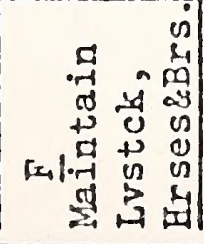 & 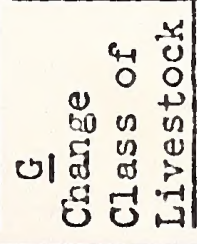 & 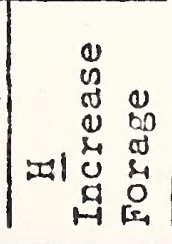 \\
\hline
\end{tabular}



IV. Persons, Groups and fovernment Agencies Consulted

Susanv11le D1strict Adv1sory Board

Calffornia Department of Floh and Game

Nevada Department of F1sh and Game

Cal-Neva Resource Conservation and Development District

Representatives of Slerra Club

Bureau of Sport Flsheries and W1ldife

v. S. Forest Service

Lassen Ecological Forum

\section{Intensity of Public Interest}

The proposed program of w1ld horse and burro management has generated

a great deal of interest, but not much controversy. However, as more specific plans and procedures are developed it w111 probably generate some controversy.

\section{Participating Staff}

R. Gregg Berry, Ass1stant Area Manager, Surprise Resource Area, Coordinator

Myron Adams, Watershed Management

Arnold Bullock, Range Management

George Farris, Wildl1fe Management

Roger Zortman, Area Manager, PIt Rlver Resource Area

George Welsk1rcher, Recreation

Donald R. Wilbur, Range Conservationist 

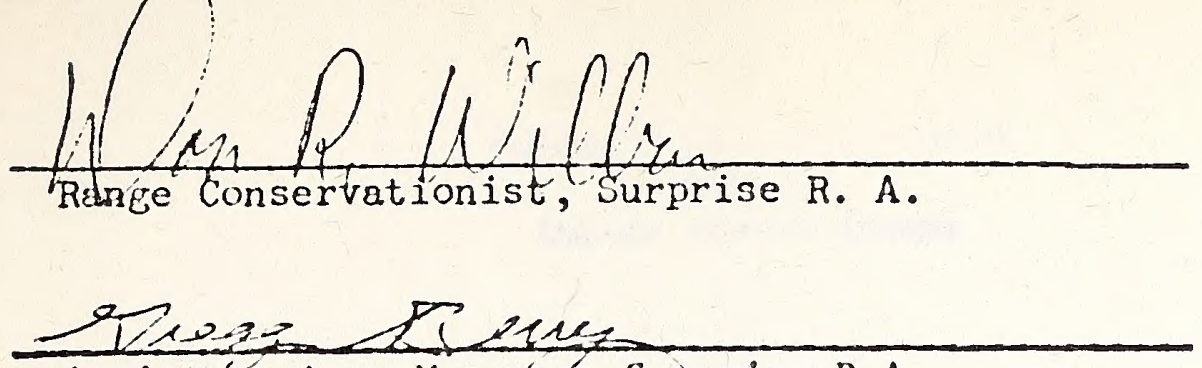

Assistant Area Manalgr. Sutprise R.A.
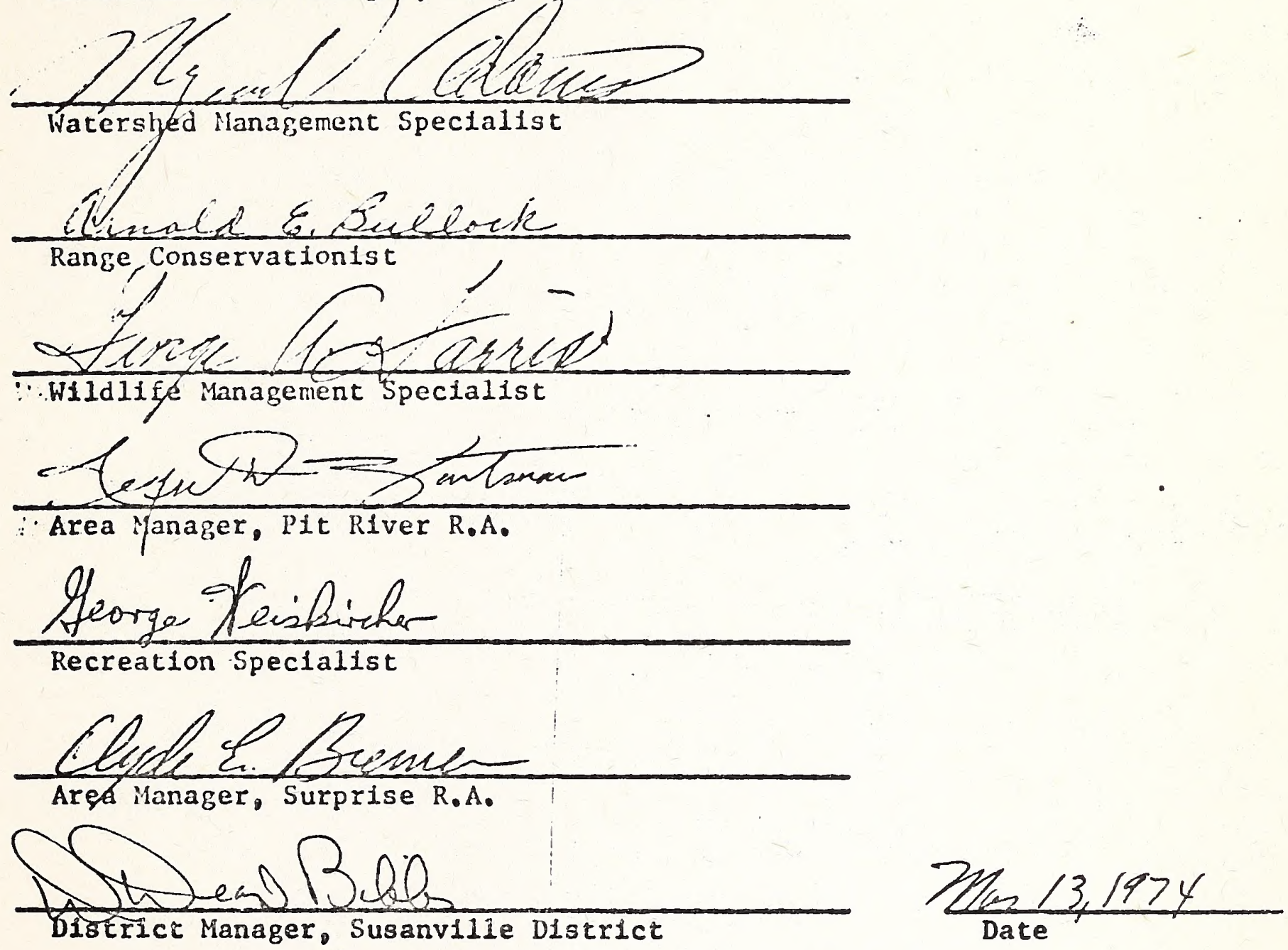

52 


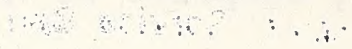


Bureau of han. a ment

Etoraty

Denvor somes enener 
